\title{
How to Compensate the Damages Arising from a Contaminated Blood Transfusion in the Legal Systems of Iran and Europe
}

\author{
Zahra Esmaeilpour ${ }^{1}$ \\ ${ }^{1}$ Islamic A zad University, East Azarbaijan Science and Research Branch, Iran \\ Correspondence: Zahra Es maeilpour, Master Student of Private Law, Islamic A zad University, East Azarbaijan \\ Science and Research Branch, Iran.
}

Received: June 16, 2016 Accepted: July 18, 2016 Online Published: July 31, 2016

doi:10.5539/jpl.v9n6p194 URL: http://dx.doi.org/10.5539/jpl.v9n6p 194

\begin{abstract}
At the end of the last century, transmission of viral diseases such as AIDS and HIV through blood transfusions to patients with "Hemophiliacs", to kick up a row the discussion about civil liability arising from contaminated blood transfusion in the case called "Hemophiliacs" end trying to get it drew Hemophiliacs material and moral damage prompted the judiciary. A mong the many factors blood transfusion process are involved the responsibility of each of them is subject to certain regulation.

For example blood centers, hospitals, doctors, nurse who transfuse the infected blood and resulting that injured party forced to use the infected blood and at the end state because of providing and distribution of blood as a public service. Blood center has a safety commitment and mast distribute a blood to be free of and implication. So they are responsible. Just with transfusion unless they reveal other factors and causes in fact in this case, the most important issue is the way of compensation of injured parties. So not only material remedies resulting transfusion of infected blood is indemnify. But in this point view that no damages should not be remain compensation. In addition mo ral damages and .........

So because of importance of the subject and importance of the compensation of injured parties, it's essential to base on.... Theory, implication absolute liability and objective liability for state with assuming the direct role of the state in the management of medical procedures in public hospitals. And the possibility of the direct role of the state in their affliction and regarding the role of the state in public health.
\end{abstract}

Keywords: commit ment to safety, civil liability, infected blood, causality,damage

\section{Introduction}

Blood donation is the donation of life, but not always the case. Today, the spread of viral incurable diseases such as AIDS and hepatitis can occur through blood transfusions, which violate this sentence. In the meantime, legal liability resulting from blood transfusions infected with HIV and hepatitis B and C would confronts the society with different legal issues. It should be considered that among the various factors in the process of blood transfusion (blood transfusion centers, hospitals and health clinics that injected contaminated blood to the patient and the physicians who ordered the prescription of blood transfusion and other cases) which one is responsible for compensation. On the other hand, the causal relationship between contaminated blood and caused loss is noteworthy; because, apart from blood, other factors may also cause transmission of the virus and medically, there is not any method for the diagnosis of infected blood transfusion. Another issue is the damage and how to evaluate it. Accordingly, the in jured party may asks what kind of damage (financial, spiritual, physical) and have what criteria to assess the damage. There are two solutions to respond to these issues. First, using the trad itional tools of civil liability and second, new instruments to compensation that can be seen today in the form of compensation funds and there is an example of these developments in the Iranian Law. On the other hand, the traditional tools of civil liability require new interpretation and analysis to be able to solve these dile mmas.

\section{How to Compensating the Damages Caused to Patients in France}

In France, the leg islator has appointed a specific procedure for compensation in order to combat the spread of AIDS and hepatitis C and B and accordingly, a special fund has been established based on public solidarity in order to compensate for these losses. The budget required for this fund is financed through public funds and insurers, so that the plaintiffs in the field of contaminated blood can receive their compensation without having 
to hold the trial. Two models are anticipated to compensate for losses in these funds.

A. The condition in which a patient completely infected with HIV. In this case, after the certainty of HIV infection, the funds and organizations that pay the compensation, must deposit the amount set by the court over three consecutive times. This cost is funded through public funds and should be determined through an agreement between the court and the organizations that pay the compensations.

B. In this model, the person is not still infected with AIDS and hepatitis c but medical tests indicate the presence of this virus in his body, but the virus has not shown its true face and is not active. In this case, the judicial procedures in the French courts is that the patient has the right to receive moral and material compensation.

\section{Amount and Procedure of Compensation for Damages to Patients in Iran}

According to the verdict of Branch 1060 of Tehran General Court on June 13, 2004, amount and how to compensate the material damage any of the claimants with HIV and hepatitis $\mathrm{c}$ is thus divided.

A. Those who have died as a result of HIV, the survivors should receive the blood money of a man and two million Tomans for med ical expenses before death.

B. Those living patients should be evaluated in order to get a full compensation payments and medical expenses.

C. those patients who have been diagnosed with hepatitis c should receive full compensation payments and medical expenses up to 17 million Tomans.

In addition, the organization provides a basis for future problems associated with unpredictable situation in Hepatitis $\mathrm{C}$ and the patients can refer to Legal Medicine Organization with respect to changes in his health status.

D. Those people who have been infected through contact with blood, blood products, hemophilic patients and other recipients such as wife and children. If this is a disease according to tests conducted by the Legal Medicine Organization. They are included in the A, B and C and a warrant is is sued for the payment of blood money.

In addition to material damages, this verdict must be taken into account such things as employ ment, education, deprivation of marriage to those who have been infected with HIV and hepatitis C. The court argued that there is no criterion for determining moral damages. And the legal obligations contained in Articles 40, 164, 167 of the constitution and Articles 1, 2, 3, 4, 5 and 11 of the law of civil liability and Article 477 of Islamic Penal Code, with regard to paragraph 3 of Article 2 of the International Civil and Political Rights, adopted in 1975, that is based on Article 9 of the Civil Code in domestic law and with regard to legal rules, especially rule of "Would do no harm" and considering the government's authority in this matter (Ministry of Health and the Department of Transfusion Medicine), thus it is argued that moral damages, including loss of life expectancy, uncertainty about the future, physical and mental pains, fear of the future, social is olation, deprivation of marriage, deprivation of having a child and other cases should be compensated.

The court has issued a final decision for compensation for people infected with HIV and hepatitis c through contaminated blood:

1) Individuals infected with hepatitis c under 18 years nearly 20 percent of the blood money of a man.

2) Unmarried individuals infected with hepatitis c over 18 years with high school diploma equivalent to 35 percent of the blood money of a man

3) Unmarried individuals infected with hepatitis c over 18 years with high school diploma equivalent to 35 percent of the blood money of a man

4) Unmarried individuals infected with hepatitis c over 18 years with Bachelor's degree equivalent to 40 percent of the blood money of a man

5) Unmarried individuals infected with hepatitis c over 18 years with post-graduate education equivalent to 50 percent of the blood money of a man

6) Married individual under dip lo ma equivalent to 40 percent of the blood money of a man

7) Married individuals with high school diploma equivalent to 45 percent of the blood money of a man

8) Married individuals with higher education equivalent to 55 percent of the blood money of a man

9) Married individuals with post-graduate education equivalent to 65 percent of the blood money of a man

10) Married individual with children and under diploma equivalent to 50 percent of the blood money of a man

11) Married individual with children and high school diploma equivalent to 55 percent of the blood money of a 
man

12) Married individual with children and education higher than diploma equivalent to 60 percent of the blood money of a man

13) Married individual with children and MA and higher education equivalent to 70 percent of the blood money of a man

14) Students who are studying at the as sociate, undergraduate, master, doctoral are included in the div is ion above, regardless of the remaining of their education.

15) Because hepatitis $\mathrm{C}$ can lead to liver cancer and the patient is forced to graft liver, the court must decide in such cases.

In addition to paying the moral and material damages, the defendants must rehabilitate the plaintiff in widely circulated newspapers and this text must be sent to all of them.

In Iranian courts, HIV infection moral damage is equivalent to a full blood money and this money must be paid to the person or his heirs, in addition to material damages.

With emphasis on the fact that the legal heirs should benefit from moral damages, the provisions concerning the moral and material losses in accordance with paragraph 5 and 6 in the law of civil liability laws, it must be said that it is not possible to determine the consequences of injuries. And the compliant can ask an appeal for two years.

\section{Comparative Studies in Other Countries}

Those who were infected with HIV through contaminated blood began their efforts to obtain compensatio $\mathrm{n}$ from 1985 and there is strength and weaknesses in different countries. In the information released by the World Federation of Hemophilia which was updated in 1995, the countries whose data are available, divided into several groups:

1) Countries that support patients with HIV and will help them through NGOs and certain committees. Successful examples are A merica, Brazil and Belgium.

2) Countries that support patients with AIDS and compensation paid to them: Canada, Denmark, Hong Kong, Hungary, Israel, Italy and Portugal.

3) Countries that handle the situation of AIDS patients through recourse to the judiciary and condemning the governments and companies to pay compensation: Bulgaria, Fin land, India, Malta, New Zealand, Norway and Sweden.

4) Countries where patients with AIDS are supported by the public sector and private sector: Australia, France, Germany, Ire land, Japan, Netherlands, South Africa, Spain and England.

5) Countries where patients receive indirect support through social welfare organizations. In fact, the Patient Advocate Association benefit from the support: Cuba, Greece and Thailand.

In all countries, the age of persons infected with HIV is intended in order to pay compensation. More compensation is awarded to adults. There are two ways to pay compensation: at once or a monthly basis during the life of the person with AIDS. About the latter, some measures intended to adapt the amount of money with economic inflation.

For example, in Canada, an AIDS patient receives thirty thousand dollars annually.

Heirs also receive twenty thousand dollars per year for 5 years. In Hong Kong, payment of compensation to patients with AIDS through contaminated blood products is as follows:

Patients who have a spouse and children receive one million dollars; Patients who have only wife received seven hundred and fifty thousand dollars; unmarried patients received six thousand dollars; children who have been infected with HIV receive three thousand dollars; relatives of a patient who have been infected through this patient receive three thousand dollars.

The Japanese government has set for hemophiliacs over 18 years 2328 dollars per month and for hemophiliacs under this age has set 947 dollars per month. Lithuanian government has set 415 thousand dollars as compensation for each patient and also paid 1350 do llars monthly to patients.

\section{Measures Taken in Respect of Compensation for Each Country}

Ireland: 
Under certain conditions to make investments with financial backing, hemophiliacs infected with HIV grant amounts listed in the table is based on the amount received and depending on their family situation. There are two ways to pay: at once or weekly. Establishment of such a credible investment prevented legal recourse of 73 hemophiliacs to health care institutions, blood transfusion services, hospitals and doctors. The cost of the first installment depends on the family situation of the patient which was paid in September 1991.

England:

In September 1987, the government established a venture capital fund called Mcfarlane Fund. In earlier work, the money in the fund was used for common tasks such as payments associated with different seasons, inclu ding heating system and the like. Since March 1990, the fund has paid \$ 35,000 for compensation. However, in October 1990, 962 people were eager to receive aid. Therefore, the assets of the fund depends on the financial status of families. However, it is expected that 30 to 40 patients a total of 1217 patients with hemophilia request that health level should be raised and the authorities should be more careful about the money.

Australia:

In November 1989, the Australian federal government established an independent investment fund called (Mark Fitzpetrick investment fund). The fund provides financial assistance to those who medically were infected with HIV. It was thought that the $\$ 7,000$ would help reduce the an xiety caused by the high cost of HIV infection . There are no funds for these patients in order to compensate low inco me and poor hygiene.

The Government proposes that hemophilic patients with HIV should turn to the courts to get compensation. As a result, they benefited from a legal protection. Hemophilia Association of Australia stated that these patients are also suffering from depression due to stress and trauma. A Hemophilic patients be able to receive a compensation of \$ 645000 worth from Alfred Hospital, Victoria blood transfusion service and serological laboratory. He donated the money to the hospital which pay the cost of treating patients. The hospital decided against the request. They had given the money to the state as financial help. This irony was able to induce the local government that they should pay more attention to hemophiliacs in this part of the country. In May 1990, it was decided that all residents in West Australia need to do an AIDS test. Moreover, 223000 dollar was paid to hemophiliacs infected with HIV. In addition, the Western Australian government took over responsibility for the health of these people. Federal States in the northern and southern followed the plan and agreed to pay financial assistance to AIDS patients. In these areas, patients receiving 111,000 to 445,000 dollars and a guarantee for the continuity of med ical care.

Germany:

According to legal liability for pharmaceutical companies, Hemophilia Association negotiating with insurance companies and Pharmaceuticals could pass a law to pay for damages caused by the infection. The amount of aid for each patient was amongst 28000 to 216000 and depends on the social and educational level of the subjects and their wives also received $\$ 15,000$. The money was given to a living husband or wife with low income or no income. Association gathered an asset and pay the money. The maximum value is $\$ 111,000$. In late 1987 , almost all demanders of financing were settled.

Swis :

From 1988, the Association of Hemophilia tried to get \$35,000 for each HIV-infected hemophiliacs and they tried to allocate $\$ 14,000$ to solve the financial problems in the Association. By 1991, the government allocated an amount of $\$ 35,000$ for hemophiliacs who were infected with HIV through contaminated blood or their partners.

Previously, Hemophilia Society has established a fund of $\$ 56,000$ that the capital has increased by the Swiss Red Cross and Immano A G. Each of these institutions assigned \$ 700,000 for emergency tasks of hemophilia Association. These amounts did not create any debt to Switzerland. So in effect this aid in injuries and damages caused by negligence and forgetfulness was a very low level at least.

\section{New Approaches to Compensation Losses in Excess of Blood Money}

Diya or blood money due to violation of the integrity of the global financial specifies that gender should legally be paid exiles. Blood money right under Article 15 of the Penal Code "financial blood money that has been set by the legislator for the crime." But blood money is the special nature of what is certain is that in all cases (both criminal and civil liability compensation) compensation aspect can be seen in it. Now the question is whether the legislator has determined the exact amount of blood money, all losses measure and there is no other possibility to claim damages other than blood money or is it only covers blood money moral damage caused by crime, such as 
pain and suffering the victims have endured, along with other damages claim is of course provided that the circu mstances have demanded. A mong contemporary scholars are those who claim damages in excess of limited blood money.

In courts of justice, some courts have confirmed losses in excess of atonement. The General Board of the Supreme Court cannot insist that a vote be legally binding for other courts ruled out the possibility of a claim for damages in excess of blood money.

In the vote which was issued on December 05, 1989, Court of First Instance which insisted on the possibility of a claim for damages in excess of compensation payments, have been violated: "Demands Court of Appeal judgment and reasoning is flawed because demand claim for damages caused by the crime of traumatic brain injury and skull fracture of Shahab Zandi been handled in criminal court and the Criminal Court in its ru ling has given the amount of blood money in accordance with the law. Therefore, the claim for losses incurred by the person for the same crime as a result of follow-up other than blood money is unlicensed."

On June 25, 1996, another vote, unlike the previous vote by General Board of the Supreme Court below was issued. "... Acts committed by the defendants, a public assault victim leading to bone fractures leg. In addition to the sentence, defendants were sentenced to pay losses. According to the relevant provisions of blood money, prohibiting payment of other damages could not be inferred. Because the purpose of damages is the actual losses. Therefore, derived from Articles 1, 2, 3, the law of civil liability and no harm by taking the general rule and the rule of causality and the need to compensate for these losses have no problem ...". Because the material is present the Islamic penal code, therefore, there is no limit on compensation for damages and compensation payments that can be paid only material damages.

\section{Instances of Damage in Excess of Blood Money}

Losses in excess of blood money includes numerous examples. But the main problem is the cost of treatment and dis ability compensation that will be discussed in detail.

\section{A) The cost of treatment}

The cost of the damaged traditionally spends his treatment of perspective, loss or damage and life is that bodily injury is inflicted upon a savior, so as mentioned previously seen as not merely a penal institution. But blood money to compensate all damages and also requires that if the blood money is sufficient for the cost of treat ment, excess amount is not being discussed is that if blood money does not provide enough care costs, now the excess cost can be requested? It is analy zed that if we accept the cost of treatment is commonly loss or damage that the victim entered and any damage or loss should be compensated. So the culprit is obliged to fully compensate the damage as much as possible into the situation he had first come, including loss treatment costs should be paid by the importer of losses. We might ask: Why would the cost of treatment has no determinate size and the second question is that we direct causal relationship between the costs of treatment and there is no criminal harmful practice. The injured party may recover without treatment if the patient is achieved. The first answer is obvious, because there are cases where the applicant wants to calculate the cost of treat ment. To determine the amount of it, it is left to the experts to determine the costs due to the circumstances and the judge will senten ce accordingly.

In answer to the second question must be said that there is a common need for treatment. Otherwise, pay for the cost of treat ment is not compulsory; but the culprit pays blood money, so the injured party pays this cost himself. But he put the cost to do in an emergency. As a result, there is a relationship between the damage and this cost and the culprit is considered as a "cause".

\section{B) Disability compensation}

If the occurrence causing damages and losses suffered by the victim and disable him for a while and he couldn't be able to pay maintenance expenditure for his family (Vahdati Shobeiri, 2011, S248-262).

There are two forms of disability:

1) Temporary disability: in this case, the person improved and gain its work force in this type of dis ability, which are facing losses of the past.

Now the question is whether the limitation period for a claim for damages or not. The same issue of law raised in the discussion of guarantee that if one worker is detained or otherwise be hindered him. Should instead the interests of the deceased should be paid to compensate? The answer to this question is controversial. Comments of jurisprudents is that is not responsible, the human being is free and his interests obey his function, as human being cannot be usurped. As a result, the interests of free man cannot be occupied by another person. However, a group of scholars believes in responsibility and believe that you should not be a detriment to others. But in 
response to famous jurists, it can be argued that this cannot be considered as usurpation, but there isn't any obstacle to implementing rules such as waste and causality. However, being deprived from job does not create any guarantee and he must be emp loyed before the accident and the amount of damage at the time of the incident should be considered (Doroudian, 1995, p. 91).

2) Permanent disability: in this case, the inju red worker is dimin ished or completely destroyed. For example, the adverse effect of treatment for spinal cord injury, and is permanently disabled, pursuant to Article 5 of the Civil Liability damage assessment by the Court. And the court to compensate the los due to the circumstances of the case or to continually determines the time units and if the effect of physical injury is present at the time of sentencing is not possible, court to two years from the date of issue will have a right of appeal against the sentence (Shoja' Nouri, 2010, p. 248 and 249). And if accepted, what kind of accepted it and has stated in its judgment. Now we want to examine whether the judge's decision tainted blood money damages in excess of accepted or rejected it. Today, most judges tend to compensation in excess of their blood money. Such as fairness and justice is closer to the position of the blood money for compensation in excess of the stated problem. The question of whether we should or should not be asked for damages in excess of the blood money if the damage is irreparable physical damage? Undoubtedly, the answer is yes. Because no harm should remain without compensation, blood money must be entered in damages, Losses in excess of the blood money enters and causes property damage which is different and can be made about causality order to recoup losses on property (Badini et al., 2012, p. 5). In the vote, known as hemophilia, the court after reviewing the circumstances and conditions, claim their votes in three aspects: physical, spiritual and damages in excess of the blood money, to be determined, the blood money damages in excess of the cost of the treatment only aspect of the damage was voted for in excess of the blood money. But more than these demands in the petition had been filed and a judge should be asked within the framework given by the plaintiff to file for vote. Since the compensation method based on infra-esteem and it is reported in Shiite Jurisprudence and blood money; on the other hand, with regard to the technical nature of the subject, since it can determined by the type and amount of damage based on the forensic expertise, therefore, the court issued a specific subject matter experts to suit the particular importance of the damage, in order to prevent any possible violation of rights, and completely expert on theory and specialized medical committee composed of three legal experts, the result will be announced by the treatment and costs are as follows:

The rate of health care costs on the defendant is equivalent to 125000000 Rials.

Complications occurred on patients is equivalent to $50 \%$ of blood money of man and now he improved or not.

\section{Liability Insurance}

Consumer rights and the need to support it for a long time as one of the key topics discussed were right and technological progress and dramatic expansion of the manufacturing process has increased its importance. The consumer is a person who is against the manufacturer, distributor, vendor or supplier and he bought and consumed in order to meet the needs and manufacturers and others can meet this need.

Among the most important methods that are used for consumer protection in European countries is non-governmental organizations. NGOs consumer protection is one of the ways of consumer's rights protection, these organizations are independent of governments and the partnership offers spontaneous crystallization. In most cases, there are some pressure groups whose common goals are trying to improve consumer rights, information about the necessity of providing quality products to consumers, criticizing the quality of goods, litigation in the courts on behalf of consumers and so on; And trying to pass appropriate laws and regulations and to communicate with non-governmental organizations in other countries and international organizations on consumer protection can be one of the most important tasks of this organization in support of consumer righ ts (Sadeghi and Montahi, 2010, p. 3).

In addition to non-governmental organizations, liability insurance is also important that support consumer and supplier, at the same time.

One of the factors that influence in the field of civil liability is the role that insurance plays; this legal entity that made such an impression in the field of civil liability and civil liability law, which can certainly say that in today's society without insurance, nobody not being able to perform its task (Khodabakhshi Shamzari, 2002, p. 102).

Liability insurance of product, the responsibility of the manufacturer, importer, wholesaler and retailer to the consumer in exchange for financial and physical damages caused by defective goods to market consumer gets covers, this insurance is not mandatory, but sets of different rules for the protection of consumers and buyers, 
influential people in the supply chain for consumers and contractors responsible knows almost absolute and so have virtually all manufacturers to provide product liability insurance.

Iran's parliament has passed a law for blood and blood products and has allocated a budget of 2.5 billion Tomans for Blood Transfusion Organization. If successful, it will be a major step in ensuring the rights of consumers of blood and blood products in our country; in this process, the important matter is to share the benefits of insurance to consumers, especially consumers of blood and blood products is permanent; this insurance can be profitable, if the situation does not happen in which they have to pay compensation to a large number of consumers. On the other hand interests of consumers are not infected with a dangerous virus that may be transmitted to them through blood and blood products. Without a doubt, associations, patient advocacy organizations typically are the best insurers in the development of the new process in Iran, including the Iranian Hemophilia Society Foru m.

Insurance assignment in blood products to private sector is beneficial for governments and consumers. Certainly, the presence of insurer private organizations in the process of blood collection and distribution of blood and blood products inextricably linked with the proper functioning of blood transfusion. On the other hand, correct functioning of insurance companies would have significant benefits. For example, an insurer that insures organization and its products. In order to predict an accident, before the injection of blood and blood products, one ought to do viral testing and these tests should be recorded in the medical record. In another example of how we can document the status of permanent consumers of blood and blood products to benefit from this type of insurance, the private sector is not possible. Health without filing for individual patients with hemophilia and thalassemia and dialysis patients covered by insurance to make blood products.

\section{Support Fund}

With the discovery of viruses such as HIV and hepatitis B and A and the pollution caused by it, resulted in some countries establish organizations to support and compensation and these losses can be compensated on the basis of national solidarity and by the establishment of a special fund.

Unfortunately, in Iran, there aren't any rules and solutions in order to compensate for the damage caused by a contaminated blood transfusion. And so far no legal personality, whether public or private, has claimed responsibility for compensation to consumers of contaminated blood.

And the legal obligations contained in Articles 40, 164, 167 of the constitution and Articles 1, 2, 3, 4, 5 and 11 of the law of civil liability and Article 477 of Islamic Penal Code, with regard to paragraph 3 of Article 2 of the International Civil and Political Rights, adopted in 1975, that is based on Article 9 of the Civil Code, the court will be able issue a warrant in order to compensate for material and moral damage in these patients. Accordingly, in the famous case of hemophilia, the court issued a warrant in order to compensate for material and moral damages based on the same issue. Without a doubt, vacuum created by the absence of special rules for compensation of the loss to be felt and the involvement of leg is lator in this field is essential. But the verdict will be effective for the compensation, when an entity or a special organization intended to compensate for losses caused by medical accidents. However, there is no such entity in Iran and the court of Administrative Justice is not qualified to deal with complaints against the government or government agencies and jurisdict ion over the claims are exclusively in the courts or criminal law. (Abbasi et al., 2009, p. 90).

Unlike Iran, there is a coherent system for payment of compensation in France. Accordingly, fund and private organizations have been established to pay compen sation in order to facilitate these payments.

Prior to the Act of March 4, 2002that the predicted special regime for medical compensation, compensation follows the general ru les of civil liability. The law was adopted on 31 December 1991 whereby a special fund was established. According to the law, if a person is infected with HIV through contaminated blood, must pay compensation through the fund.

The funding in the general budget and part of it is funded by insurers. Terms of payment of compensation by the Fund is as follows. The losses should be caused by infection with the AIDS virus. Second, the disease should be occurred by contaminated blood transfusion. Third, the contamination must be occurred in the territory of France. Compensation from the fund includes all direct and indirect moral and material damages. However, the current compensation through the fund is based on this important principle that civil liability wants to compensate for damages; as a result, the injured cannot obtain benefits in this way. So if injured by another, including litigation, has received compensation from the fund is not entitled to damages. It also forecasts that the injured have any objection to the decisions of the fund is able to see the Paris court of appeal and complaint.

After the compensation fund is able, on behalf of the aggrieved person see the person responsible for the 
contamination and all damages get paid. With the approval of Act of March 4, 2002, the compensation for medical accidents based on specific regimen extended to other cases (Kazemi, 2007, pp. 223 and 224).

According to what was mentioned, one will find that many countries are looking to explore new ways for compensation for persons who used the contaminated blood products. And in this regard, measures have been carried out by these countries and one of them was presented.

Thus, with the growing number of patients who were infected with AIDS and hepatitis through contaminated blood transfusion and with respect to inadequacy of the traditional rules of civil liability, it is suggested that a special law should be adopted in this area for this type of compens ation.

\section{Conclusion}

The study achieved these results after the general comment:

1) Liability arising from a contaminated blood transfusion is based on the theory of risk. The reason is that blood transfusion organization is exclusively responsible for the production of blood and blood products. According to the blood transfusion service is a government entity so harmful acts attributed to the government in this regard, Blood Transfusion Organization commitment in this area a safety pledge of commitment to the result, should give blood free of any contamination. So if blood is contaminated with viruses such as hepatitis c, these viruses cause infection, based on the theory of risk should be allowed to take responsibility for the government's objective, because, firstly, the recipient's acceptance of the theory of fault proved difficult factors involved in blood transfusion. Second, while not damaged and not the agent causing harm (here is the Blood Transfusion Organization) are depreciation, according to the theory of fault should a heavy burden on the shoulders of the injured party's damages. While accepting the risk theory to solve the above problems and responsibility for administration will determine the objective.

2) To document the causal link between the transfusion and the risk of the patient, can be attributed to other causes by resorting to the argument negating the existence of a causal relationship. This means that when a person after receiving blood or blood products infected with HIV or hepatitis and certainly not obvious that the blood transfusion is the cause of infection or there is another cause for the infection, it is assumed that the infection was due to blood transfusion and in fact, the blood was infected with a virus. Thus, under the argument of "negation of other reasons," factors that are likely to be the cause of the contamination, should be negated and one of the causes is the "blood transfusion" and should be considered as the main cause.

3) By studying the legal systems of Iran and France, and how to handle claims of AIDS or hepatitis caused by contaminated blood transfusion; the legislator has appointed a specific procedure for compensation in order to combat the spread of AIDS and hepatitis C and B and accordingly, a special fund has been established based on public solidarity in order to compensate for these losses. The budget required for this fund is financed through public funds and insurers, so that the plaintiffs in the field of conta minated blood can receive their compensat ion without having to hold the trial. However, in Iran, any organization, ranging from private and public, is not responsible for the pay ment of compensation to the victims in these incidents. But according to the principles of the 40, 164167 different substances constitution and law of civil liability and Article 9 of the Civil Code the court can order compensation for the material and moral.

4) given that many factors are involved. In a contaminated blood transfusion, for compensation, this should be done by the "theory of the causes and conditions" and all the factors are responsible for compensation.

And finally, according to what was stipulated in paragraph 1, the final responsibility is on the shoulders of the government. As the French case law has used the same strategy to compensate for the damages sustained.

At the end, this study provide the following recommendations:

The legislator, in particular judicial commission in Parliament, be suggested that a special institution should be established to compensate for damage caused by a contaminated blood transfusion. Secondly, rules should be established in order to facilitate proof of causality between blood transfusion and losses. Thirdly, the judges is recommended to use experiences in other countries as long as the law is not approved. According to the "commitment to safety", blood Transfusion Center is responsible for losses incurred by individuals in a contaminated blood transfusion, because the organization is required to provide a blood disease-free.

\section{References}

Abbasi, M., Shokr Amerji, A., \& Mohammadi, S. (2009). a comparative study of liability arising from a contaminated blood transfusion in the legal system of Iran and France, Tehran, Iranian Journal of Medical Law. 
Badini, H., A mraeifard, M., \& Rahpeik, H. (2012). the first session of analysis and criticis mof judicial decisions focused on hemophilia case, the University of Judicial Sciences.

Doroudian, H. (1995). civil rights booklet 4. Tehran University Press.

FLOUR, J., \& Aubert, J.-L. (1999). Les obligations,T.2. Le fait jurdique. Armand Colin.

Gout, O. (2002). Conceotion extensive du lien de causalite, JCP.

Huet, J. (1986). Le Paradox, des mé dicaments: responsabilité pharmaceutique etriésgue dé veloppement, RTD civ.

Jourdain, P. (2001). Imputabilité d'une contamination viral d'une trans fusion, sanguine, RTD civ.

Kazemi, M. (2007). civil liability arising from a contaminated blood transfusion, Tehran, Journal of Law, Facu lty of Law and Political Science at Tehran University.

Khodabakhshi ShamzarI, A. (2002). the effect of the law of civil liability insurance. Tehran, Tehran University Press.

Lambert-Faivre, Y. (1996). Droit de dommage Corporel (3rd ed.). Dalloz.

Le Tourneau, Ph. (1974). Droit de la responsabilité et des contrats, Dalloz.

M.de Foges. (1992). Side: Responsibilité, indeminisation des Prejudices resultant de Contamination par transfusion sanguine, RD Sanit. Soc 1992.

Pansier, F.-J. (2002). Cinquante Commentaires des arréts en droit des obligations ellipse.

Petition 1237; dated on December 23, 2004 and issued by Branch 15 of Tehran Appeals Court.

Petition 246-9, dated on May 14, 2005 and issued by Branch 9 of the Supreme Court.

Petition 78 to 1052, dated on October 04, 2004 and issued by Branch 1060 of Tehran Public Court.

Petition No. 8809970226100239, dated on 04.31.2009, issued by Branch 1 of the Tehran public court, classifieds case No. 8509980226100340.

Petition No. 8809970226100244; Issued in branch 1 of Legal General Court, Judiciary Complex of martyr Beheshti University, Tehran, Classifieds case 45/99802261003.

Sargos, P. (1999). Réflextion sur les accidents médicaux, et la donctrine jurisprudentielle de la cour de cassation en matié re de la responsabilité Mé dicale,D., chron.

Shoja pouri, S. (2010). contractual liability of physician against patient. Tehran, Ferdowsi publication.

TERRé, F., SIMLER, PH.et Lequette, Y. (1999). Droit civil, Les obligation,7e ed., Dalloz.

Vahdati Shobeiri, H. (2006). the princip les of contractual liability, Qom, Islamic Sciences and Cult ure Academy.

Vahdati Shobeiri, H. (2008). Base and territory of compensation surplus on blood money, Islamic Studies, Qom, Journal of Jurisprudence and Principles.

Viney, G. (2003). Trait de droit civil,les conditions de la responsabilité, sous la direction de la responsabilité J.GHESTIN, 2ed., L.G.D.J.1998. responsabilité du médecin, Litéc.

\section{Copyrights}

Copyright for this article is retained by the author(s), with first publication rights granted to the journal.

This is an open-access article distributed under the terms and conditions of the Creative Commons Attribution license (http://creativecommons.org/licenses/by/4.0/). 